\title{
HUBUNGAN PERAWATAN PAYUDARA DAN KONSUMSI ENERGY DENGAN KELANCARAN ASI PADA IBU MENYUSUI
}

\author{
The Corellation Breast Care And Energy Consumtion With Smooth Breastmilk In \\ Breastfeeding Mother
}

\author{
Dewi Kartika Sari \\ Fakultas Ilmu Kesehatan Universitas Kadiri \\ dewikartika@unik-kediri.ac.id
}

\begin{abstract}
Abstrak
Menyusui merupakan hal yang paling penting untuk mendukung pertumbuhan bayi terutama pada usia 0-6 bulan. Prevalensi pemberian ASI Eksklusif di kota kediri pada tahun 2015 sebesar 64,5\% yang masih dibawah target sebesar $80 \%$. Penelitian ini bertujuan untuk mengetahui faktor yang berhubungan dengan kelancaran ASI yaitu perawatan payudara dan konsumsi energi.

Desain penelitian ini adalah analitik korelasional (correlational study) dengan pendekatan cross sectional. Penelitian ini menggunakan instrument lembar checklist, angket formulir recall 24 jam dan kuesioner, dengan purposive sampling diperoleh sampel 30 responden. Uji statistic Chi Square dan multivariat menggunakan Regresi linier.

Dari analisis multivariat menunjukan hasil ada hubungan perawatan payudara dan konsumsi energy dengan kelancaran ASI pada ibu menyusui di Kota Kediri Tahun 2018, namun diantara 2 faktor tersebut yang paling berhubungan adalah konsumsi energy dengan hasil $p=0,017$ dan $R R=10,6$ hal ini menunjukan bahwa konsumsi energy yang baik bisa 10,6 kali melancarkan ASI.

Ibu menyusui harus melakukan perawatan payudara dan konumsi energy. Hal ini perlu dilakukan dengan cara mengajari ibu tentang perawatan payudara dan memberi anjuran pada ibu untuk mengkonsumsi energi yang baik setiap hari agar ASI yang diproduksi bisa lancar sehingga bayi mendapatkan gizi yang maksimal untuk pertumbuhnya.
\end{abstract}

Kata kunci : perawatan payudara, konsumsi energi, ASI

\begin{abstract}
Breastfeeding is the most important thing to support infant growth especially at $0-6$ months of age. The prevalence of exclusive breastfeeding in the city of 2015 by $64.5 \%$ is still below the target of $80 \%$. This study aims to determine the factors associated with the smooth breastfeeding of breast care and energy consumption.

The design of this research is correlational study (correlational study) with cross sectional approach. This research use instrument checklist sheet, 24 hour recall and questionnaire, with purposive sampling obtained sample 30 respondents. Chi Square and multivariate statistics test using linear regression.

From the multivariate analysis showing the results there is a relationship of breast care and consumption of energy with the smoothness of breast milk in breastfeeding mothers in the City of Kediri Year 2018, but among the two most related factors is the energy consumption with $p=0,017$ and $R R=10,6$ this shows that good energy consumption can be 10,6 times breastfeeding.

Breastfeeding mothers should perform breast care and energy consumption. This needs to be done by teaching mothers about breast care and giving advice to mothers to consume good energy every day so that the milk produced can be smoothly so that babies get the maximum nutrition for growth.
\end{abstract}

Keywords: breast care, energy consumption, breast milk 


\section{PENDAHULUAN}

Air Susu Ibu merupakan makanan yang paling dibutuhkan untuk bayi usia 0-6 bulan untuk memenuhi gizinya pada 1000 hari pertama kehidupan (Kemenkes, 2013). Banyak ibu nifas yang mengeluh produksi ASInya tidak lancar, banyak factor penyebab ASI tidak lancar selain factor stress ternyata factor gizi juga mempengaruhi produksi ASI (Pertiwi dkk, 2012).

Berdasarkan survei yang dilakukan oleh badan penelitian dan pengembangan di bidang kesehatan, pada tahun 2013 didapatkan 46\% ketidak lancaran ASI terjadi akibat perawatan payudara yang kurang, 25\% akibat frekuensi menyusui yang kurang dari 8x/hari, 14\% akibat BBLR, 10\% akibat prematur, dan 5\% akibat penyakit akut maupun kronis (Depkes 2013). Kelancaran ASI pada ibu menyujui juga dipengarui konsumsi energy melalui perilaku pola makan yang memenuhi asupan nutrisi yang merupakan perilaku paling penting yang dapat mempengaruhi keadaan gizi. Menurut data Profil Kesehatan Indonesia pada tahun 2012 persentase cakupan pemberian ASI di Indonesia sebesar 48,6\%. Persentase pemberian ASI tertinggi adalah di provinsi Nusa Tenggara Barat sebesar 69,84\% dan sedangkan Jawa Timur sendiri menempati urutan 6 terendah yaitu sebesar 34,38\% (Dinkes, 2013). Pada tahun 2016 presentase ibu menyusui Provinsi Jawa Timur terhadap konsumsi Energi mencapai $73,8 \%$, protein $91,9 \%$, karbohidrat $73,7 \%$, lemak $78,3 \%$ (Profil Kesehatan Jawa Timur, 2016). Sedangkan data di Kota Kediri tahun 2015 jumlah bayi yang diberi ASI eksklusif sebesar $2.462 \quad(64,5 \%)$ dimana jumlah tersebut masih belum memenuhi target ASI eksklusif yang ada di Indonesia.

Dari data diatas menunjukan bahwa masalah ASI merupakan masalah yang penting yang harus diatasi mengingat pentingnya manfaat ASI bagi pertumbuhan bayi, ASI yang terproduksi lancar akan memenuhi gizi bayi terutama bayi usia 0-6 bulan. Salah satu upaya untuk menunjang kelancaran ASI selain dari gizi yang optimal juga perawatan payudara. Diperlukan tambahan energy sebesar 800 kkal pada ibu menyusui, dengan rincian $600 \mathrm{kkal}$ untuk produksi ASI dan 200 untuk proses menyusui
(Pertiwi dkk, 2012). Tambahan gizi ini tidak hanya diugunakan untuk kebutuhan tubuh ibu menyusui saja, tetapi juga untuk produksi ASI yang diberikan kepada bayi (Carpenito, 2009). Konsumsi energi yang dilakukan ibu nifas sebagai bentuk pemenuhan kebutuhan asupan nutrisi ibu nifas dapat menunjang kelancaran ASI, peraatan payudara penting dilakukan sebagai tindakan yang mendukung kelancara ASI (Sari, 2017).

Selain gizi, perawatan payudara merupakan suatu tindakan perawatan payudara yang dilaksanakan baik oleh ibu post partum maupun dibantu oleh orang lain yang dilaksanakan mulai hari pertama atau kedua setelah melahirkan. Kelancaran ASI dan kecantikan payudara pasca menyusui juga tergantung pada perawatannya (Nur sholichah, 2015).

Berdasarkan latar belakang diatas perlu adanya kemauan ibu nifas untuk melakukan perawatan payudara dan konsumsi energy sebagai penunjang terhadap produktifitas ASI maka peneliti tertarik untuk melakukan penelitian dengan judul "Hubungan perawatan payudara dan konsumsi energy terhadap kelancaran ASI pada ibu menyusui di Kota Kediri Tahun 2018”.

\section{METODE PENELITIAN}

Desain yang digunakan dalam penelitian ini adalah desain analitik korelasional (correlational study) dengan pendekatan cross sectional. Disebut korelasional karena penelitian ini bertujuan untuk mengetahui hubungan perawatan payudara dan konsumsi energy terhadap kelancaran ASI pada ibu menyusui di Kota Kediri Tahun 2018. Populasi dari penelitian ini adalah seluruh ibu menyusui di kota kediri dan sampel pada penelitian ini adalah sebagian ibu menyusui di kota kediri. Penentuan sampel menggunakan purposive sampling dan didapatkan 30 sampel. Proses pengambilan data menggunakan kuesioner. 
HASIL PENELITIAN

Dari hasil penelitian diperoleh data sebagai berikut:

Tabel 1. Distribusi Frekuensi Perawatan Payudara pada Ibu Menyusui

\begin{tabular}{ccc}
\hline $\begin{array}{c}\text { Kriteria Perawatan } \\
\text { Payudara }\end{array}$ & Frekuensi & Persen \\
\hline Kurang Baik & 18 & $60 \%$ \\
Baik & 12 & $40 \%$ \\
\hline Total & 30 & $100 \%$ \\
\hline Berdasarkan & hasil & penelitian yang
\end{tabular}

terdapat pada tabel diatas menunjukkan sebagian besar responden perawatan payudara kriteria kurang baik yaitu sebanyak 18 responden $(60 \%)$.

Tabel 2. Distribusi Frekuensi Konsumsi Energy pada Ibu Menyusui

\begin{tabular}{lcc}
\hline \multicolumn{2}{c}{ Kriteria } \\
$\begin{array}{c}\text { Konsumsi } \\
\text { Energy }\end{array}$ & Frekuensi & Persen \\
\hline Kurang Baik & 15 & $50 \%$ \\
Baik & 15 & $50 \%$ \\
\hline Total & 30 & $100 \%$ \\
\hline \multicolumn{3}{c}{ Berdasarkan hasil penelitian yang } \\
terdapat pada tabel diatas menunjukkan \\
setengah responden konsumsi energy kriteria \\
baik yaitu sebanyak 15 responden (50\%).
\end{tabular}

Tabel 3. Distribusi Frekuensi Kelancaran ASI pada Ibu Menyusui

\begin{tabular}{ccc}
\hline $\begin{array}{c}\text { Kriteria } \\
\text { Kelancaran ASI }\end{array}$ & Frekuensi & Persen \\
\hline Kurang Lancar & 14 & $46,7 \%$ \\
Lancar & 16 & $53,3 \%$ \\
\hline Total & 30 & $100 \%$ \\
\hline Berdasarkan & hasil penelitian yang
\end{tabular}

terdapat pada tabel diatas menunjukkan sebagian besar responden kelancaran ASI kriteria lancar yaitu sebanyak 16 responden $(53,3 \%)$.

Tabel 4. Tabulasi Silang Perawatan Payudara dengan Kelancaran ASI pada Ibu Menyusui

\begin{tabular}{|c|c|c|c|c|c|c|}
\hline \multirow{4}{*}{$\begin{array}{l}\text { Perawatan } \\
\text { payudara }\end{array}$} & \multirow{2}{*}{\multicolumn{4}{|c|}{$\begin{array}{c}\text { Kriteria Kelancaran } \\
\text { ASI }\end{array}$}} & \multirow{3}{*}{\multicolumn{2}{|c|}{ Total }} \\
\hline & & & & & & \\
\hline & \multicolumn{2}{|c|}{$\begin{array}{l}\text { Kurang } \\
\text { Lancar }\end{array}$} & \multicolumn{2}{|c|}{ Lancar } & & \\
\hline & $\mathrm{F}$ & $\%$ & $\mathrm{~F}$ & $\%$ & $\mathrm{~F}$ & $\%$ \\
\hline Kurang & 12 & 40 & 6 & 20 & 18 & 60 \\
\hline Baik & 2 & 6,7 & 10 & 33,3 & 12 & 40 \\
\hline Jumlah & 14 & 46,7 & 16 & 53,3 & 30 & 100 \\
\hline \multicolumn{3}{|c|}{$\alpha=0,05$} & \multicolumn{4}{|c|}{$\rho=0,007$} \\
\hline
\end{tabular}

Berdasarkan tabulasi silang hasil penelitian terdapat pada tabel diatas menunjukkan sebagian besar responden dengan perawatan payudara kriteria kurang didapatkan kelancaran ASI kurang sebanyak 12 responden (40\%). Sedangkan hasil analisis menggunakan uji Chi Square didapatkan $p$ value $=0,007<\alpha 0,05$ maka Ho di tolak dan $\mathrm{H} 1$ diterima artinya ada hubungan perawatan payudara dengan kelancaran ASI pada ibu menyusui di Kota Kediri Tahun 2018.

Tabel 5. Tabulasi Silang Konsumsi Energy dengan Kelancaran ASI pada Ibu Menyusui

\begin{tabular}{clllccc}
\hline & \multicolumn{3}{c}{ Kriteria Kelancaran } \\
Konsumsi \\
\cline { 2 - 6 } Energi & \multicolumn{3}{c}{ Kurang } & \multicolumn{2}{c}{ Lancar } & \multirow{2}{*}{ Total } \\
& \multicolumn{2}{c}{ Lancar } & & & & \\
\cline { 2 - 6 } & $\mathrm{F}$ & $\%$ & $\mathrm{~F}$ & $\%$ & $\mathrm{~F}$ & $\%$ \\
\hline Kurang & 11 & 36,7 & 4 & 13,3 & 15 & 50 \\
Baik & 3 & 10 & 12 & 40 & 15 & 50 \\
\hline Jumlah & 14 & 46,7 & 16 & 53,3 & 30 & 100 \\
\hline \multicolumn{2}{c}{$\alpha=0,05$} & & \multicolumn{5}{c}{$\rho=0,003$} \\
\hline
\end{tabular}

Berdasarkan tabulasi silang hasil penelitian terdapat pada tabel diatas menunjukkan sebagian besar responden dengan konsumsi energi kriteria baik didapatkan kelancaran ASI kriteria lancar sebanyak 12 responden (40\%). Sedangkan hasil analisis menggunakan uji Chi Square didapatkan $p$ value $=0,000<\alpha 0,003$ maka Ho di tolak dan H1 diterima artinya ada hubungan konsumsi energi dengan kelancaran asi pada ibu menyusui Kota Kediri Tahun 2018.

Tabel 6. Hubungan Perawatan Payudara, Konsumsi Energi dan Kelancaran ASI Pada Ibu Menyusui

\begin{tabular}{lcccc}
\hline \multicolumn{1}{c}{ Variabel } & Sig & Exp(B) & $\begin{array}{c}\text { Nagelkerke R } \\
\text { Square }\end{array}$ \\
\hline $\begin{array}{l}\text { Perawatan } \\
\text { Payudara }\end{array}$ & 0,033 & 9,628 & 0,512 & \\
$\begin{array}{l}\text { Konsumsi } \\
\text { Energi }\end{array}$ & 0,017 & 10,632 & & \\
\hline \multicolumn{1}{c}{ Dari } & data & diatas & diperoleh hasil
\end{tabular}
diantara perawatan payudara dan konsumsi energi, yang paling berhubungan dengan kelancaran ASI adalah konsumsi energi dengan hasil 0,017 dan RR 10,632 yaang berarti konsumsi energi yang baik maka 10,632 kali melancarkan ASI. 


\section{PEMBAHASAN}

Dari hasil analisis semua variabel diperoleh hasil adanya hubungan perawatan payudara dan konsumsi energi dengan kelancara ASI pada ibu menyusui, namun dari perawatan payudara dan konsumsi energi, yang paling berhubungan dengan kelancran ASI adalah konsumsi energi dengan hasil $p=0,017$ dan RR 10,632 yaang berarti konsumsi energi yang baik maka 10,632 kali melancarkan ASI.

Asupan energi merupakan hal yang penting yang harus terpenuhi pada masa menyusui, energi banyak dibutuhkan pada masa ini, selain untuk memperbaiki kondisi pada masa nifas, energi juga dibutuhkan untuk memproduksi ASI, konsumsi energi juga berhubungan dengan produksi ASI untuk peningkatan berat badan bayi (Sari, 2017). Pernyataan ini juga sejalan dengan hasil penelitian yang menyebutkan adanya hubungan antara perawatan payudara dan konsumsi energi dengan kelancaran ASI. ASI penting bagi pertumbuhan bayi, ASI yang terproduksi lancar akan memenuhi gizi bayi terutama bayi usia 0-6 bulan.

Selain konsumsi energi, faktor lain yang berhubungan dengan kelancaran ASI adalah perawatan payudara. Perawatan payudara masa menyusui, pada saat hamil ukuran payudara memang membesar karena bertambahnya saluran-saluran air susu, sebagai persiapan laktasi. Kondisi payudara biasanya akan berubah-ubah setelah tiga hari setelah melahirkan. Namun itu bukan berarti tidak ada cara membuat payudara terlihat indah dan kencang. Apalagi setelah persalinan dan disaat menyusui. Selain terlihat indah, perawatan payudara yang dilakukan (Saleha, 2013).

Produktifitas ASI dipengaruhi oleh perawatan payudara, dimana perawatan payudara dapat mempengaruhi produktifitas ASI, sebagaimana beberapa faktor yang mempengaruhi produksi ASI yaitu Frekuensi pemberian susu, Perawatan Payudara, Kecukupan Gizi/konsumsi energy, Berat bayi saat lahir, Usia kehamilan saat melahirkan, Usia ibu dan paritas, Stress dan penyakit akut, Memgkonsumsi rokok, Mengkonsumsi alkohol, Pil kontrasepsi (Saleha, 2013). Hal ini juga sejalan dengan penelitian ini yang menunjukan adanya hubungan perawatan payudara dengan kelancaran ASI. Produksi ASI memang harus diperhatikan salah satu caranya dengan perawatan payudara agar ASI tetap lancar sehingga gizi bayi terpenuhi dan pertumbuhan menjadi optimal.

\section{KESIMPULAN}

Ada hubungan antara perawatan payudara dan konsumsi energi dengan kelancaran ASI pada ibu menyusui.

\section{DAFTAR PUSTAKA}

Carpenito, L.J. 2009. Diagnosis Keperawatan dan Aplikasi Praktik Klinis. Jakarta: ECG

Depkes RI 2013. Manajemen Laktasi Buku Paduan Bagi Petugas Kesehatan di Puskesmas. Jakarta: Direktorat Gizi Masyarakat.

.Dinkes Jatim 2016. Profil Kesehatan Jawa Timur 2016. Surabaya : Dinkes Jatim.

Kementrian Koordinator Bidang Kesehatan RakyatRI, 2013. Gerakan Nasional Percepatan Perbaikan Gizi Dalam Rangka Seribu Hari Pertama Kehidupan (Gerakan 1000 HPK). RepublikIndonesia

Nur sholichah, 2015. Hubungan Perawatan Payudara Pada Ibu Postpartum Dengan Kelancaran Pengeluaran ASI - Semarang : Jurnal Penelitian Kebidanan

Pertiwi, S.H, Solehawati \& Widiasih. 2012. Faktor-Faktor yang Mempengaruhi Proses Laktasi Ibu dengan Bayi Usia 0-6 Buan di Desa Cibeusi Kecamatan Jatinangor. Jurnal Universitas Padjadjaran: Bandung.

Sari, 2017. Hubungan teknik, frekuensi, durasi menyusui dan asupan energi ibu menyusui terhadap kenaikan berat badan bayi usia 1-6 bulan di Puskesmas Tasikmadu Kabupaten Karanganyar Provinsi Jawa Tengah. Amerta Nutrition. Vol.1 No.1

Saleha. 2013. Asuhan Kebidanan Pada Masa Nifas. Jakarta : Salemba Medika.

Suradi. 2014. Manajemen Laktasi. Jakarta. Perkumpulan Perinatologi Indonesia. 